\title{
QARDHUL HASAN DALAM PERSFEKTIF HUKUM ISLAM PADA BAITUL MAAL WA TAMWIL (BMT) DAN IMPLEMENTASINYA
}

\author{
Muhamad Bisri Mustofa' ${ }^{1}$, Mifta Khatul Khoir ${ }^{2}$
}

Institut Agama Islam Agus Salim Metro

JI. Brigjend. Sutiyoso No. 7, Kota Metro, 34111, Lampung

muhamadbisrimustofa@gmail.com, miftahkhatul6494@gmail.com

\begin{abstract}
In the implementation of Islamic Financial Institutions such as the Baitul Maal wa Tamwil (BMT) there are various ways of collecting funds and channeling funds. Funds are collected through wadi'ah deposits and deposits. While the distribution of funds is done by murabahah, mudharabah, musyarakah, rahn (pawn), ijarah, ijarah multijasa and qardhul hasan financing. Qardhul Hasan's financing is the orientation of the function of the Islamic Financial Institution (Baitul Maal Wa Tamwil) as a social institution. Qardhul hasan is a soft loan given on the basis of mere social obligations. In this case the borrower is not required to return anything except the amount borrowed. In Qardhul Hasan financing there are pillars and conditions, namely the perpetrator of the contract consisting of muqtaridh (borrower), muqridh (lender), qardh (fund), shighat ijab and qabul willingness for both parties and funds used for something useful and lawful. Qardhul Hasan is an activity to achieve a predetermined goal or target by the relevant Islamic financial institutions. The mechanism for implementing Qardhul Hasan is solely aimed at providing assistance to meet the needs of small communities. Thus it can be seen that the form of borrowing through Qardhul Hasan is in accordance with the principles of sharia economic law, the potential source of Qardhul Hasan's funding is quite large if it is utilized and managed optimally and its implementation is very useful for the community.
\end{abstract}

Keywords: Qardhul Hasan, Islamic Law, BMT

\begin{abstract}
Abstrak
Dalam pelaksanaan Lembaga Keuangan Syariah seperti Baitul Maal wa Tamwil (BMT) terdapat berbagai macam cara penghimpunan dana dan penyaluran dana. Penghimpunan dana dilakukan melalui simpanan wadi'ah dan deposito. Sedangkan penyaluran dana dilakukan dengan pembiayaan murabahah, mudharabah, musyarakah, rahn (gadai), ijarah, ijarah multijasa dan pembiayaan qardhul hasan. Pembiayaan Qardhul Hasan merupakan orientasi fungsi Lembaga Keuangan Syariah (Baitul Maal Wa Tamwil) sebagai lembaga sosial. Qardhul hasan adalah suatu pinjaman lunak yang diberikan atas dasar kewajiban sosial semata. Dalam hal ini peminjam tidak dituntut untuk mengembalikan apapun kecuali sejumlah yang dipinjamnya. Dalam pembiayaan Qardhul Hasan terdapat rukun dan syarat yaitu pelaku akad yang terdiri dari muqtaridh (peminjam), muqridh (pemberi pinjaman), qardh (dana), shighat yaitu ijab dan qabul kerelaan kedua belah pihak dan dana digunakan untuk sesuatu yang bermanfaat dan halal. Qardhul Hasan merupakan kegiatan untuk mencapai tujuan atau sasaran yang telah ditentukan terlebih dahulu oleh lembaga keuangan syariah yang bersangkutan. Mekanisme penerapan Qardhul Hasan semata-mata bertujuan untuk memberikan pertolongan guna memenuhi kebutuhan masyarakat kecil. Dengan demikian dapat diketahui bahwa bentuk peminjaman melalui Qardhul Hasan sudah sesuai dengan prinsip hukum ekonomi syariah, potensi sumber dana Qardhul Hasan ternyata cukup besar apabila dimanfaatkan dan dikelola secara optimal dan implementasinya sangat berguna bagi masyarakat.
\end{abstract}

Kata Kunci : Qardhul Hasan, Hukum Islam, BMT

\footnotetext{
1 Dosen Tetap IAI Agus Salim Metro, Lampung

2 Mahasiswa Program Pascasarjana IAIN Metro, Lampung, Program Studi Ekonomi Syariah TA. 2019/2020
} 


\section{Pendahuluan}

Manusia sebagai makhluk social memiliki tujuan dan prinsip, dan dalam kehidupan antar sesama manusia terdapat suatu hubungan yang tidak dapat di pisahkan terutama dalam hal muamalah. Manusia satu membutuhkan manusia lainnya untuk memenuhi kebutuhan hidupnya. Dalam perjalanan manusia kepada kebahagian hidup di dunia dengan berkeluarga, memiliki pendamping hidup dan keturunan. ${ }^{3}$ Seorang manusia yang bertanggung jawab dan memiliki agama yang kokoh akan mencari berbagai cara yang halal untuk memenuhi kebutuhan hidup dirinya dan keluarganya.

Mayoritas Penduduk di Indonesia beragama Islam yang dalam melakukan kegiatan sehari-hari seharusnya menjadikan syariat Islam sebagai landasan dalam rangka memenuhi kehidupan dan kesejahteraan bersama, baik untuk diri sendiri maupun orang lain. Islam memerintahkan seorang muslim untuk bekerja sekuat tenaga dalam mencari rezeki yang halal lagi baik. ${ }^{4}$ Untuk memenuhi kebutuhan seseorang maupun keluarganya, seseorang dapat meminjam kepada orang pribadi. Jika kebutuhan itu untuk modal usaha, seseorang dapat meminjam kepada lembaga formal maupun non formal. Dengan cara inilah seseorang akan mendapatkan penghasilan untuk memenuhi kebutuhannya.

Saat ini telah berkembang berbagai program pada berbagia lembaga keuangan syariah yang dapat dimanfaatkan untuk kepentingan masyarakat. Seiring dengan meningkatnya tingkat kebutuhan masyarakat di Indonesia baik dari segi pangan sandang dan papan maka banyaknya pertumbuhan usaha-usaha kecil di kalangan masyarakat guna memenuhi kebutuhannya masing-masing. Munculnya usaha-usaha tersebut tentu tidak terlepas dari modal dalam menjalankan kegiatannya. Dalam memperoleh modal maka pihak pengusaha akan mencari lembaga keuangan yang dapat membantu dalam hal pembiayaan (finance).

Berkaitan dengan permodalan, bagi usaha ekonomi kecil permodalan merupakan aspek kursial. Usaha kecil pada umumnya memiliki modal yang sangat terbatas sehingga berkontribusi besar pada lambatnya akumulasi modal yang menyebabkan usaha kecil ini tidak memiliki cadangan modal. Akibatnya, ketika terjadi kelesuan usaha kecil mengalami die out. ${ }^{5}$ Kendala permodalan bagi pengusaha kecil umumnya tidak mampu dipenuhi oleh perbankan modern. Pada umumnya mereka tidak bankable untuk memutuskan kreditnya. Sehingga banyak usaha kecil yang mengalami kesulitan permodalan. Kondisi ini semakin memperlebar jarak usaha kecil dan sektor informal dengan industri perbankan formal. ${ }^{6}$ Dari perjalanan tersebut, lahirlah konsep ekonomi yang berlandaskan pada nilainilai pemberdayaan dan pembangunan masyarakat khususnya kelas menengah kebawah yaitu konsep ekonomi kerakyatan. Konsep ekonomi kerakyatan adalah gagasan tentang cara, sifat, dan tujuan pembangunan dengan sasaran utama perbaikan nasib masyarakat pada umumnya bermukim di pedesaan. Konsep ini mengadakan perubahan penting kearah kemajuan, khususnya kearah pendobrakan ikatan serta halangan yang membelenggu sebagian besar rakyat Indonesia dalam keadaan serba kekurangan dan keterbatasan.

Salah satu Lembaga Keuangan Syariah non bank yang menyalurkan dana kepada masyarakat adalah BMT (Baitul Maal Wa Tamwil). Ini adalah sistem keuangan yang lebih sesuai dengan kondisi usaha kecil dan sesuai dengan Syariah. Dalam operasionalnya BMT tidak saja berperan menyalurkan dana kepada masyarakat mampu dan kalangan menengah yang mempunyai jaminan saja. Akan tetapi juga menyalurkan dana kepada pengusaha kecil atau masyarakat kurang mampu yang mempunyai potensi ketrampilan usaha. Yang menjadi keunggulan BMT dari aktivitas sosialnya adalah

${ }^{3}$ Muhamad Bisri Mustofa, Hukum Nafkah Terhadap Keluarga pada Gerakan Dakwah Jama'ah Tabligh, Jurnal Nizham, Vol. 7, No. 1 (2019), h. 1

${ }^{4}$ Abdurrachaman Qadir, Zakat (Dalam Dimensi Mahdah Dan Sosial), Ed.1.Cet.2 (Jakarta: Raja Grafindo Persada, 2001), h. 24

5 Muhammad Akhyar Adnan, Evaluasi Performing Loan (NPL) Pinjaman Qardhul Hasan (Studi Kasus di BNI Syariah Cabang Yogyakarta), Jurnal Perbankan, Vol. 10, No. 2, h. 159.

${ }^{6}$ Ridwan, M., Managemen Baitul Maal Wa Tamwil, (Yogyakarta: UII Press Yogyakarta, 2004), Cet. Pertama., h. 32 
skim pembiayaan Qardhul Hasan. Produk ini hanya diperuntukkan bagi masyarakat kurang mampu untuk membangun dan mengembangkan usahnya. ${ }^{7}$

BMT merupakan salah satu lembaga keuangan syariah non bank yang bersedia membantu para pengusaha dalam hal permodalan.dan Qardhul Hasan merupakan pinjamann sosial yang diberikan tanpa adanya bunga dan ini bersifat lunak karena hanya dituntut mengembalikkan modal awalnya saja dengan jumlah yang sama dengan pinjaman yang diterima angoota secara jangka waktu yang telah ditentukan atau diperjanjikan oleh pihak lembaga keuangan syariah. ${ }^{8}$ Pada perkembangan selanjutnya untuk pemberdayaan ekonomi sebagai usaha membangkitkan aktivitas para usaha kecil, maka dibentuklah Baitul maal yang berkonsentrasi kepada pembinaan dan pengembangan usaha kecil dengan sistem syariah yang berbagai hasil dan merupakan lembaga koersial. ${ }^{9}$

Banyak bank-bank syariah yang tersebar diseluruh Indonesia, namun pada kenyataannya belum mampu menyentuh masyarakat kalangan menengah kebawah. Masyarakat kalangan menengah kebawah pada umumnya nyaris tidak tersentuh dan tidak dianggap memiliki potensi dana oleh lembaga keuangan formal, sehingga menyebabkan laju pertumbuhan ekonomi terhambat. Faktanya, mayoritas masyarakat kalangan menengah kebawah banyak yang terjebak meminjam kepada rentenir. ${ }^{10}$

Qardhul hasan merupakan salah satu produk yang didalamnya terkandung misi sosial. Adanya misi sosial kemasyarakatan ini akan meningkatkan citra baik dan meningkatkan loyalitas masyarakat terhadap BMT. Akad qardh merupakan akad yang memfasilitasi transaksi peminjaman sejumlah dana tanpa adanya pembebanan bunga atas dana yang dipinjam oleh anggota. Transaksi qardh pada dasarnya merupakan transaksi yang bersifat sosial karena tidak diikuti dengan pengambilan keuntungan dari dana yang dipinjamkan. ${ }^{11}$ Pada dasarnya pinjaman qardhul hasan diberikan kepada mereka yang memerlukan pinjaman konsumtif jangka pendek untuk tujuan-tujuan yang sangat mendesak dan juga para pengusaha kecil yang kekurangan dana tetapi mempunyai prospek bisnis yang sangat baik. ${ }^{12}$ Oleh sebab itu penulis ingin melihat bagaimana persfektif hukum ekonomi syariah memandang Qardhul Hasan dan implementasinya di masyarakat. Dasar-dasar hukum yang digunakan dalam pelaksanaan Qardhul Hasan adalah berdasarkan dari ayat Al-Quran sesuai dengan Fatwa Dewan Syariah Nasional No. 19/DSN-MUI/IX/2000

1. QS. Al-Baqarah: 282:

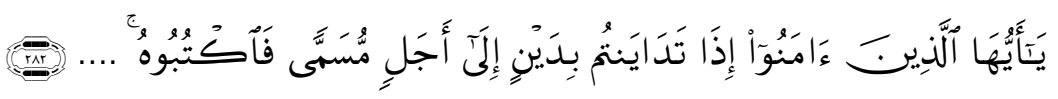

Artinya : "Hai orang-orang yang beriman, apabila kamu bermuamalah tidak secara tunai untuk waktu yang ditentukan, hendaklah kamu menuliskannya".

2. QS. al-Hadid: 11:

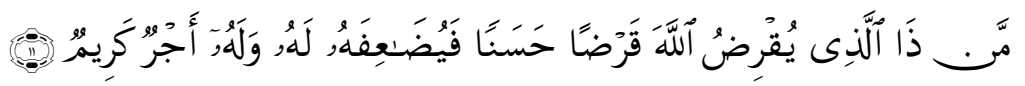

Artinya : "Siapakah yang mau meminjamkan kepada Allah pinjaman baik, maka Allah akan melipatgandakan (balasan) pinjaman itu untuknya, dan ia akan memperoleh pahala yang banyak"

ljma". Para ulama telah menyepakati bahwa Qardhul Hasan boleh dilakukan. Kesepakatan ulama ini didasari tabiat manusia yang tidak bisa hidup tanpa pertolongan dan bantuan saudaranya.

${ }^{7}$ Dedi Riswandi, Pembiayaan Qardhul Hasan Di Bank Syariah Mandiri Kota Mataram, Jurnal Hukum Islam, Vol. 14, No. 2, (2015), h. 253

8 Ascarya, Akad \& Produk Bank Syariah. (Depok: Raja Grafindo Persada Jakarta, 2015), Cetakan ke-5, h. 46

${ }^{9}$ Mulyaningrum, Peluang dan Tantangan dalam Pengembangan Lembaga Keunagan Mikro Syariah, (Tesis tidak diterbitkan, Universitas Kebangsaan Malaysia (UKM), 2009), h. 45

10 Muhammad, Bank Syariah: Problem dan Prospek Perkembangan di Indonesia, (Yogyakarta: Graha Ilmu, 2005), h.125

11 Rijal Yaya, Aji Erlangga Martawireja, Ahim Abdurahim, Akuntansi Perbankan Syariah Teori dan Praktik Kontemporer, (Jakarta: Salemba Empat, 2014) h. 288

12 Karnaen Perwataatmadja dan Muhammad Syafi'i Antonio, Apa dan Bagaimana Bank Islam (Yogyakarta: Dana Bhakti Wakaf, 1992), h. 34 
Tidak ada seorang pun yang memiliki segala barang yang dibutuhkan. Oleh karena itu, pinjammeminjam sudah menajdi satu bagian dari kehidupan di dunia ini. Dan, Islam adalah agama yang sangat memerhatikan segenap kebutuhan umatnya. Berdasarkan Fatwa DSN tersebut, maka yang menjadi pertimbangan Dewan Islam Nasional menetapkan Qardhul Hasan sebagai sebuah sistem perekonomian yang sah menurut islam.

Yang menjadi landasan dalil dalam ayat ini adalah kita diseur untuk "meminjamkan kepada Allah", artinya untuk membelanjakan harta dijalan Allah. Selaras dengan meminjamkan kepada Allah, kita juga diseur untuk "meminjamkan kepada sesama manusia", sebagai bagian dari kehidupan bermasyarakat.13

Meminjamkan yang bermanfaat bagi sesama umat muslim yang menggunakan akad Qardhul Hasan juga termasuk dari ayat di atas. Pinjaman tersebut pada masa kini dapat berupa modal usaha, seperti yang sudah ada di lembaga-lembaga yang memiliki program bantuan pinjaman dana untuk masyarakat kurang mampu dengan menggunakan akad Qardhul Hasan.

Sedangkan hadis yang sesuai dengan akad Qardhul Hasan adalah sebagai berikut:

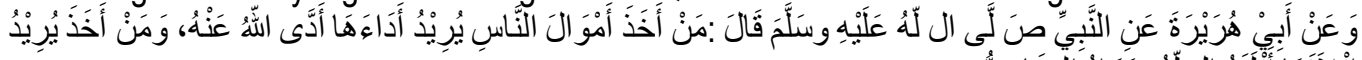

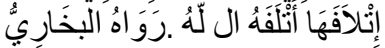

Artinya : "Artinya: "Dari Abu Hurairah Radhiyallahu Anhu, dari Nabi Shallallahu Alaihi wá Sallam bersabda, "barangsiapa mengambil harta orang lain dengan maksud untuk mengembalikannya, maka Allah akan menolongnya untuk dapat mengembalikannya; dan barangsiapa yang mengambilnya dengan maksud untuk menghabiskannya, maka Allah akan merusaknya."(HR. Al-Bukhari). ${ }^{14}$

Maksud dari hadis di atas adalah mengambil harta orang lain dengan cara berhutang dan menjaganya yang mempunyai niat untuk mengembalikannya, maka Allah akan memberikan kemudahkan untuk melunasi hutangnya tersebut. Dan apabila harta tersebut diambil untuk dihabiskan maka Allah akan mempersulit segala urusan dan keinginannya di dunia. Dalam hadits juga terdapat motivasi untuk memperbagus niat dan menghindari hal yang sebaliknya, serta menjelaskan bahwa inti perbuatan berada pada hal tersebut. Siapa yang berhutang dengan niat untuk melunasinya niscaya Allah membantu melunasinya. ${ }^{15}$

\section{Baitul Maal wa Tamwil (BMT) Pengertian}

BMT adalah kependekan dari kata Balai Usaha Mandiri Terpadu atau Baitul Maal wa Tamwil, yaitu Lembaga Keuangan Mikro (LKM) yang beroperasi berdasarkan prinsip-prinsip syariah. BMT sesuai namanya terdiri dari dua fungsi utama, yaitu: ${ }^{16}$

a. Baitul maal (rumah harta), menerima titipan dana zakat, infak dan sedekah serta mengoptimalkan distribusinya sesuai dengan peraturan dan amanahnya.

b. Baitul tamwil (rumah pengembangan harta), melakukan kegiatan pengembangan usaha-usaha produktif dan investasi dalam meningkatkan kualitas ekonomi pengusaha mikro dengan antara lain mendorong kegiatan menabung dan menunjang pembiayaan kegiatan ekonomi.

Dengan demikian, keberadaan BMT dapat dipandang memiliki dua fungsi utama, yaitu sebagai media penyalur pendayagunaan harta ibadah seperti zakat, infak, sedekah dan wakaf, serta dapat pula bersifat produktif sebagaimana layaknya bank. Sebagai lembaga keuangan, BMT juga berfungsi sebagai lembaga ekonomi. Sebagai lembaga keuangan BMT bertugas menghimpun dana dari masyarakat (anggota BMT) dan menyalurkan dana kepada masyarakat (anggotalBMT). Sedangkan

\footnotetext{
${ }^{13}$ Muhammad Syafi'i Antonio, Bank Syariah dari Teori ke Praktek, h. 132.

14 Imam al-Buhari dan Abu Hasan al-Sindi, Sahih al-Buhari bihasiyat al-Imam al-Sindi, juz II, (Lebanon: Dar al-Kitab al-IImiyah, 2008), h. 105.

15 Muhammad bin Ismail Al-Amir Ash-Shan'ani, Subulus Salam Syarah Bulughul Maram, Penerj. Ali Nur Medan, Jilid 2, (Jakarta: Darus Sunnah Press, 2008), h. 431.

${ }^{16}$ Andri Soemitra, M.A., Bank dan Lembaga Keuangan Syariah, Edisi Pertama (Jakarta : Kencana Prenadamedia Group, 2009), h. 451.
} 
sebagai lembaga ekonomi, BMT berhak melakukan kegiatan ekonomi, seperti mengelola kegiatan perdagangan, industri dan pertanian. ${ }^{17}$

\section{Qardhul Hasan \\ Pengertian}

Definisi Qardh (Pinjaman) menurut fiqih, qardh atau iqradh secara etimologi berarti pinjaman. Secara terminologi muamalah adalah "memiliki sesuatu yang harus dikembalikan dengan pengganti yang sama. ${ }^{18}$

Qardhul hasan berasal dari konsep qardh yang ada di masa Nabi Muhammad saw. Secara literal berarti "memotong suatu bagian." Sedangkan secara terminologis berarti pertukaran suatu harta atau benda dengan kewajiban bagi penerima untuk menanggung porsi yang sama atas yang diterimanya dari pemberi pinjaman, untuk dapat dimanfaatkan oleh penerima barang tersebut. ${ }^{19}$ Adapun pengertian qardhul hasan menurut beberapa sumber sebagai berikut :

a. Qardh merupakan pinjaman kebajikan/ lunak tanpa imbalan, biasanya untuk pembelian barang-barang yang dapat diperkirakan dan diganti sesuai berat, ukuran dan jumlahnya. ${ }^{20}$

b. Al-Qardh merupakan pemberian harta kepada orang lain yang dapat ditagih atau diminta kembali sesuai dengan jumlah uang yang dipinjamkan, tanpa adanya tambahan atau imbalan yang diminta oleh Bank Syariah/ Lembaga Keuangan Syariah. ${ }^{21}$

c. Al-Qardh adalah harta yang diberikan oleh pemberi utang (muqridh) kepada penerima utang (muqtaridh) untuk kemudian dikembalikan kepadanya (muqrid) seperti yang diterima, ketika ia telah mampu membayarnya. ${ }^{22}$

d. Dalam literatur fiqih klasik al-qardh dikategorikan dalam 'aqad ta'awuni atau akad saling membantu dan bukan transaksi komersial. ${ }^{23}$

Dari pengertian diatas penulis menyimpulkan bahwa yang dimaksud dengan qardhul hasan adalah sebuah produk dimana produk ini merupakan produk ta'awun (tolong menolong) dimana dana ini bersumber dari zakat, infaq dan sedekah yang bersifat sosialis dan bukan untuk kebutuhan konsumtif semata, tetapi untuk kebutuhan mendesak seperti biaya pengobatan, pendidikan dan lainlain.

Secara etimologi, qardh berarti potongan, sedangkan pengertian secara terminologi berarti pemberian harta kepada orang lain yang dapat diminta kembali dengan jumlah yang sama atau dengan kata lain meminjamkan tanpa mengharapkan imbalan atau tambahan. ${ }^{24}$

Sedangkan Qardhul Hasan adalah suatu interest free financing. Kata "hasan" berasal dari bahasa arab yaitu "insan" yang artinya kebaikan kepada orang lain. Qardhul Hasan yaitu jenis pinjaman yang diberikan kepada pihak yang sangat memerlukan untuk jangka waktu tertentu tanpa harus membayar bunga atau keuntungan. Penerima Qardhul Hasan hanya berkewajiban melunasi jumlah pinjaman pokok tanpa diharuskan memberikan tambahan apapun. Namun penerima pinjaman boleh saja atas kebijakannya sendiri membayar lebih dari uang yang dipinjamnya sebagai tanda terima kasih kepada pemberi pinjaman. Tetapi hal tersebut tidak boleh diperjanjikan sebelumnya di muka. ${ }^{25}$

Qardhul Hasan atau benevolent loan adalah suatu pinjaman lunak yang diberikan atas dasar kewajiban sosial semata, dimana si peminjam tidak dituntut untuk mengembalikan apapun kecuali

17 Ibid., h. 452

18 Wini Arintasari, Analisis Sistem Pengendalian Intern Terhadap Keputusan Persetujuan Pembiayaan pada Koperasi Jasa Keuangan Syariah di Baitul Maal wa Tamwil Anda Salatiga (Salatiga: Skripsi tidak diterbitkan, 2013), h. 104

19 Wahbah Al-Zulayle, Financial Transaction in Islamic Jurisprudence (Translation of Al- Fiqh al-Islemiy wa 'Adillatuh), Vol.1, 370-371.

${ }^{20}$ Ascarya, Akad dan Produk Bank Syariah (Jakarta: PT Raja Grafindo Persada, 2011), h. 46.

21 Drs. Ismail, MBA., Ak., Perbankan Syariah, (Jakarta: Kencana, 2011), h. 212.

22 Ahmad Wardi Muslich, Fiqih Muamalat (Jakarta: Amzah, 2010), h. 273.

${ }^{23}$ Muhammad Syafi'i Antonio, Bank Syariah dari Teori ke Praktik (Jakarta: Gema Insani, 2001), h. 131.

24 Ibid., h. 131 2014), 342-343

${ }^{25}$ Sutan Remy Sjahdeini, Perbankan Syariah Produk - Produk dan Aspek-Aspek Hukumnya, (Jakarta: Kencana, 
modal pinjaman. ${ }^{26}$ Pada dasarnya Qardhul Hasan merupakan pinjaman sosial yang diberikan secara benevolent tanpa ada pengenaan biaya apapun, kecuali pengembalian modal asalnya. ${ }^{27}$

Dalam perjanjian qard pemberian pinjaman memberikan pinjaman kepada pihak penerima pinjaman dengan ketentuan bahwa penerima pinjaman tersebut akan mengembalikan pinjamannya sesuai dengan jangka waktu yang telah diperjanjikan dengan jumlah yang sama dengan pinjaman yang diterima. Dengan demikian pihak penerima pinjaman tidak diperlukan untuk memberi tambahan atas pinjamannya..$^{28}$

Qardhul Hasan tergolong dalam akad tabarru'. Akad tabarru' dilakukan dengan tujuan tolongmenolong dalam rangka berbuat kebaikan (tabarru' berasal dari kata birr dalam bahasa Arab, yang artinya kebaikan). Dalam akad tabarru', pihak yang berbuat kebaikan tersebut tidak berhak mensyaratkan imbalan apapun kepada pihak lainnya. ${ }^{29}$

Pada dasarnya pinjaman Qardhul Hasan diberikan kepada:

a. Mereka yang memerlukan pinjaman konsumtif jangka pendek untuk tujuan-tujuan yang sangat urgen.

b. Para pengusaha kecil yang kekurangan dana tetapi mempunyai prospek bisnis yang sangat baik. ${ }^{30}$

Qard yang diperlukan untuk membantu usaha sangat kecil dan keperluan sosial, dapat bersumber dari dana zakat, infaq, dan sadaqah. ${ }^{31}$ Qardhul Hasan juga dikhususkan untuk membantu memberikan pinjaman kepada usaha-usaha pada sektor kecil yang umumnya mengalami kesulitan dalam mengembangkan usahanya. Pemberian pinjaman tunai untuk Qardhul Hasan tanpa dikenakan biaya apapun kecuali biaya administrasi berupa segala biaya yang diperlukan untuk sahnya perjanjian utang. Seperti bea materai, bea akta notaris, bea studi kelayakan, dan sebagainya. ${ }^{32}$

Pada hakikatnya qard adalah pertolongan dan kasih sayang bagi yang meminjam. Qard bukan suatu sarana untuk mencari keuntungan bagi yang meminjamkan, di dalamnya tidak ada imbalan dan kelebihan pengembalian. Namun yang terdapat pada qard\}ini adalah mengandung nilai kemanusiaan dan sosial yang penuh dengan kasih sayang untuk memenuhi hajat si peminjam modal tersebut. Apabila terjadi pengambilan keuntungan oleh pihak yang meminjamkan modal atau harta, maka dapat membatalkan kontrak qard. ${ }^{33}$

\section{Qardhul Hasan Menurut 4 Mazhab}

Menurut bahasa, Al Qardhu berarti potongan (Al Qath"u) dan harta yang diberikan kepada orang yang meminjam (muqtaridh) dinamakan qardh karena ia adalah satu potongan dari harta orang yang meminjam (muqtaridh), sedangkan kata hasan yang berarti kebaikan. ${ }^{34}$ Menurut hukum syara", para ahli figh mendefinisikan Qardh sebagai berikut :35

1. Menurut Madzhab Hanafi, Al qardh adalah harta benda mitsli (yang punya persamaan) yang kamu serahkan kepada seseorang dengan harapan kamu mendapat pemenuhan barang yang sama dengannya. Karenanya dalahm akad qardh disyaratkan hendaknya harta benda mitsli (yang punya persamaan).

2. Menurut Madzhab Maliki, Al qardh adalah "jika sesorang menyerahkan kepada orang lain sesuatu yang mempunyai nilai harta semata-mata untuk mengutamakan kepentingan,

${ }^{26}$ Muhammad, Sistem dan Prosedur Operasional Bank Syariah, (Yogyakarta: UII Press, 2000), 41.

27 Ibid., h. 42

28 Ismail, Perbankan Syariah, (Jakarta: Kencana, 2011), h. 212-213

${ }^{29}$ Adiwarman karim, Bank Islam Analisis Fiqih dan Keuangan, (Jakarta: PT RajaGrafindo Persada, 2004), h. 58

30 Karnaen Perwataatmadja dan Muhammad Syafi'i Antonio, Apa dan Bagaimana Bank Islam, (Yogyakarta: Dana Bhakti Wakaf, 1992), h. 34

31 Muhammad Syafi'i Antonio, Bank Syariah dari Teori ke Praktek, h. 133

${ }^{32}$ Amir Machmud dan Rukmana, Bank Syariah Teori, Kebijakan..., h. 28-29

${ }^{33}$ Atang Abd. Hakim, Fiqih Perbankan Syariah, (Bandung: PT Refika Aditama, 2011), h. 267.

34 Muhammad, Tehnik perhitungan Bagi Hasil dan Profit Margin pada Bank Syariah, (UII Press, Yogyakarta, 2004), h. 40

${ }_{35}$ Abdurrahman al-Jaziri, Kitab Fiqih Empat Madzhab, (CV. Asy Syifa', Semarang, 1994), h. 649 
dalam aarti penyerahan tadi tidak menghendaki diperbolehkannya pinjaman yang tidak halal, dengan janji dia (pemberi modal) mendapat ganti (keuntungan) dalam tanggungan, dengan syarat penggantinya tidak berbeda dengan modal yang diserahkan".

3. Menurut Madzhab Hanbali, Al Qardh adalah menyerahkan harta kepada seseorang yang dapat mengambil manfaat dan ia mengembalikan gantinya.

4. Menurut Madzhab Syafi"i, Al Qardh adalah akad perjanjian yang dibuat oleh pemiutang untuk memindahkan pemilikan harta kepada peminjam, di mana peminjam berjanji akan mengembalikan semula barang gantinya.

Dilihat dari definisi diatas, al qardh adalah suatu akad yang membawa kepada pemindahan harta milik pemiutang kepada penghutangnya dan hutang itu akan dibayar balik kepada pemiutangnya sebagaimana hutang yang diterimanya. Hutang berlaku pada harta yang bernilai (mithli). Al hasan adalah kalimah ini digandingkan dengan kalimah al qardh itu maknanya ialah "yang baik". Kalimah ini digandingkan bertujuan untuk menguatkan maksud al qardh. Kalimah al qardh sebenarnya sudah cukup menggambarkan suatu muamalah yang baik yang tidak memerlukan ganjaran faedah atau keuntungan, bahkan setiap faedah atau keuntungan ke atas pinjaman adalah riba yang dilarang oleh Allah. Kalimah al hasan yang baik itu bermaksud pinjaman yang diberikan itu adalah semata-mata suatu muamalah yang baik bertujuan untuk berbuat kebajikan kerana Allah dengan membantu seseorang. Bukan untuk tujuan berniaga atau mencari keuntungan atau mengharapkan apaapa faidah. Segala manfaat yang ada pada pinjaman, semuanya kembali kepada peminjam sematamata, pemiutang tidak mendapat apa-apa manfaat dari harta yang dipinjamnya itu. ${ }^{36}$

Secara umum, arti qardh serupa dengan arti jual beli, karena qardh adalah pengalihan hak milik harta atas harta. Qardh juga termasuk jenis salaf. Dalam literatul fiqh salaf as sholih qardh dikatagorikan dalam akad tathowui' atau akad saling bantu membantu dan bukan transaksi komersial. ${ }^{37}$

Menurut Muhammad Muslehuddin, Qardh adalah suatu jenis pinjaman pendahuluan untuk kepentingan peminjaman. Ini meliputi semua bentuk barang yang bernilai dan bayarannya juga sama apa yang dipinjamkan. Pinjaman tidak mendapatkan nilai yang berlebih karena itu akan merupakan riba yang dilarang dengan keras. ${ }^{38} \mathrm{Al}$ qardh sebagai salah satu landasan transaksi produk pembiayaan perbankan syariah mengacu kepada UU no. 21 tahun 2008 pasal 1 ayat (25) huruf d, pasal 19 ayat (1) dan (2) huruf e, dan pasal 21 huruf b angka 3. Menurut UU ini al qardh di artikan sebagai "akad pinjaman dana kepada nasabah dengan ketentuan bahwa nasabah wajib mengembalikan dana yang diterimanya pada waktu yang telah disepakati.

Menurut Fatwa DSN Indonesia : 1. Bahwa lembaga keuangan syariah (LKS) di samping sebagai lembaga komersial, harus dapat berperan sebagai lembaga social yang dapat meningkatkan perekonomian secara maksimal. 2. Bahwa salah satu sarana peningkatan perekonomian yang dapat dilakukan oleh LKS dalah penyaluran dana melalui prinsip Al Qardh, yakni suatu akad pinjaman kepada nasabah dengan ketentuan bahwa nasabah wajibmengembalikan dana yang diterimanya kepada LKS pada waktu yang telah disepakati oleh LKS dan nasabah. ${ }^{39}$

Qardh merupakan pinjaman kebajikan atau lunak tanpa imbalan, biasanya untuk pembelian barang-barang fungibel yang dapat diperkirakan dan diganti sesuai berat, ukuran, dan jumlahnya. Kata qardh ini kemudian diadopsi menjadi credo (Romawi), credit (inggris), dan kredit indonesia (indonesia). Objek dari pinjaman qardh biasanya adalah uang atau alat tukar lainnya, yang merupakan pinjaman transaksi murni tanpa bunga ketika peminjam mendapatkan uang tunai dari pemilik dana (BMT) dan hanya wajib mengembalikan pokok pinjaman pada waktu tertentu pada masa yang akan datang. Dari definisi tersebut bahwa sesungguhnya al qardh merupakan salah satu jenis pendekatan untuk

\footnotetext{
37 Muhammad Syafi"i Antonio, Bank Syariah dari Teori ke Praktik, Gema Insani Press, Jakarta, 2001, hlm. 131

38 Muhammad Muslehuddin, Sistem Perbankan dalam Islam, Rineka Cipta, Jakarta, 2004, hlm. 78.

39 Fatwa MUI, Dalam Perspektif Hukum dan Perundang-undangan, Puslitbang Keagamaan Badan Litbang dan Diklat, jakarta, 2012, hlm. 26713
}

36 Ibid., h. 338 
mendekatkan diri kepada Allah dan merupakan jenis muamalah yang tercorak ta"awun (pertolongan) kepada pihak lain untuk memenuhi kebutuhannya, karena muqtaridh tidak diwajibkan memberi iwwad (tambahan) dalam pengembalian harta yang dipinjamnya kepada muqtaridh (yang memberikan pinjaman), karena al qardh menumbuhkan sifat lemah lembut kepada manusia, mengasihi, dan memberikan kemudahan dalam urusan mereka serta memberikan jalan keluar dari duka kabut yang menyelimuti mereka.

Para ulama telah menyepakati bahwa al qardh boleh dilakukan. Kesepakatan ulama ini didasari tabiat manusia yang tidak bisa hidup tanpa pertolongan dan bantuan saudaranya. Tidak ada seorang pun yang memiliki segala barang yang ia butuhkan. Oleh karena itu, pinjam meminjam sudah menjadi bagian dari kehidupan di dunia. Islam adalah agama yang sangat memperhatikan segenap kebutuhan umatnya. ${ }^{40}$ Dari pembahasan diatas, maka dapat disimpulkan bahwa akad al qardh adalah perikatan atau perjanjian antara kedua belah pihak, dimana pihak pertama menyediakan harta atau memberikan harta dalam arti meminjamkan kepada pihak kedua sebagai peminjam uang atau orang yang menerima harta yang dapat ditagih atau diminta kembali harta tersebut, dengan kata lain meminjamkan harta kepada orang lain yang mebutuhkan dana cepat tanpa mengharapkan imbalan. Dengan kata lain, akad al qardh merupakan pinjaman oleh pihak LKS kepada nasabah tanpa adanya imbalan, perikatan jenis ini bertujuan untuk menolong, bukan sebagai perikatan yang mencari untung. ${ }^{41}$

\section{Perbedaan Qard dan Qardhul Hasan}

1. Qard adalah pemberian pinjaman kepada orang lain yang dapat ditagih kembali, sedangkan Qardhul Hasan pemberian pinjaman kepada orang lain, dimana peminjam tidak diharuskan mengembalikan pokoknya apabila dirasakan benar-benar peminjam tidak mampu untuk mengembalikannya. Sehingga Qardhul Hasan ini dianggap sadaqah. Walaupun pada prinsipnya bukanlah produk yang Profitable namun tetap harus diperhatikan sistem dari produk ini agar lebih optimal dan meminimalisir resiko yang mungkin terjadi.

2. Dilihat dari segi sumber dana, sumber dana qard berasal dari dana komersial atau modal. sedangkan sumber dana Qardhul Hasan berasal dari dana sosial yakni dana zakat, infaq, dan sadaqah.

\section{Fatwa Dewan Syariah Nasional}

Fatwa Dewan Syariah Nasional No. 19/DSN-MUI/IV/2001 tentang Qard :

\section{Pertama : Ketentuan Umum :}

1. Al Qard adalah pinjaman yang diberikan kepada nasabah (muqtarid) yang memerlukan.

2. Nasabah Al Qard wajib mengembalikan jumlah pokok yang diterima pada waktu yang telah disepakati bersama.

3. Biaya admninistrasi dibebankan kepada nasabah.

4. LKS dapat meminta jaminan kepada nasabah bilamana dipandang perlu.

\section{Kedua : Sanksi :}

1. Dalam hal nasabah tidak menunjukkan keinginan mengembalikan sebagian atau seluruh kewajibannya dan bukan karena ketidak mampuannya, LKS dapat menjatuhkan sanksi kepada nasabah.

2. Sanksi yang dijatuhkan kepada nasabah sebagaimana dimaksud butir 1 dapat berupa .. Dan tidak terbatas pada penjualan barang jaminan.

3. Jika barang jaminan tidak mencukupi, nasabah tetap harus memenuhi kewajibannya secara penuh.

1. Bagian modal LKS. Ketiga : Sumber Dana :

2. Keuntungan LKS yang disisihkan, dan

40 Hendri Hermawan A. N, Sumber dan Pengunaan Dana Qardh dan Qardhul Hasan, (La Riba Jurnal Ekonomi Islam volume 11. No, 2 Desember 2008), h. 267.

${ }^{41}$ Muhammad Syafi"i Antonio, Op. Cit, h. 131 
3. Lembaga lain atau individu yang mempercayakan penyaluran infaqnya kepada LKS. ${ }^{42}$

\section{Rukun-Rukun Qardhul Hasan}

Setiap kegiatan bermuamalah sebagai umat muslim hendaknya memerhatikan rukun-rukun yang sudah ditetapkan dalam hukum Islam, guna melengkapi suatu akad atau transaksi. Sehingga transaksi yang telah disepakati oleh kedua belah pihak dapat dinyatakan sah sesuai dengan hukum Islam. Rukunrukun Qardhul Hasan diantaranya adalah:

1. Pihak yang meminjam (Muqtarid).

2. Pihak yang memberikan pinjaman (Muqrid).

3. Barang yang dihutang/objek akad (Muqtaradl ma'qud 'alaih).

4. ljab qabul (Sighat). ${ }^{43}$

\section{Syarat-Syarat Qardhul Hasan}

1. Orang yang meminjamkan memenuhi syarat berikut :

a. Berhak berbuat kebaikan sekehendak orang tersebut

b. Manfaat dari barang yang dipinjamkan menjadi milik peminjam dan barang yang dipinjamkan menjadi milik yang meminjamkan.

2. Orang yang meminjam :

a. Berhak mendapat kebaikan

b. Dapat dipercaya untuk menjaga barang tersebut

3. Barang yang dipinjamkan :

a. Mempunyai manfaat yang dapat diambil oleh peminjam

b. Barang yang diambil manfaatnya tidak rusak karena pemakaian yang disetujui dalam perjanjian. Ulama hanafiyah berpendapat bahwa qard dipandang sah pada harta mitsil, yaitu sesuatu yang tidak terjadi perbedaan yang menyebabkan terjadinya perbedaan nilai. Diantara yang dibolehkan adalah benda-benda yang ditimbang, ditakar, atau dihitung. ${ }^{44}$

4. Lafadz atau ijab kabul :

a. Kalimat mengutangkan Lafadz

b. Mu'ir (orang yang mengutangkan) merupakan pemilik barang tersebut, dan musta'ir (orang yang berhutang) harus baligh, berakal, dan bukan orang yang tidak dimahjur

c. Benda yang diutangkan dapat diambil manfaatnya atau dimanfaatkan. ${ }^{45}$

Qard adalah bentuk akad tabarru'. Oleh karena itu, tidak boleh dilakukan oleh anak kecil, orang gila, orang bodoh, orang yang dibatasi tindakannya dalam membelanjakan harta, orang yang dipaksa, dan seorang wali yang tidak sangat terpaksa atau ada kebutuhan. Hal ini karena mereka semua bukanlah orang yang dibolehkan melakukan akad tabarru'. ${ }^{4}$

Harta yang dipinjamkan jelas ukurannya, baik dalam takaran, timbangan, bilangan, maupun ukuran panjang supaya mudah dikembalikan. Para ulama empat madzab telah sepakat bahwa pengembalian barang pinjaman hendaknya ditempat pelaksanaan akad qard dilaksanakan. Dan boleh ditempat mana saja, apabila tidak membutuhkan biaya kendaraan. Apabila diperlukan, maka bukan sebuah keharusan bagi pemberi pinjaman untuk menerimanya. ${ }^{47}$ Pinjaman mempersyaratkan penerima harus bertanggung jawab atas segala sesuatu yang dipinjamnya. ${ }^{48}$

Ketika seorang hendak meminjamkan uang kepada seseorang, alangkah lebih baik mereka membuat kontrak tertulis dengan menetapkan syarat dan ketentuan utang itu disertai dengan penetapan jatuh temponya. Kontrak atau dokumen seperti itu harus dibuat di depan dua orang saksi. ${ }^{49}$

\footnotetext{
42 DSN MUI, Qard, Fatwa DSN MUI. No. 19/DSN-MUI/IV/2001 Tentang Qard, h. 3.

${ }^{43}$ Sunarto Zulkifli, Panduan Praktis Transaksi Perbankan Syariah, (Jakarta: Zikrul Hakim, 2007), h. 27.

${ }^{44}$ Rachmat Syafe'i, Fiqh Muamalah, (Pustaka Setia: Bandung, 2001), h. 154.

45 Sarib Muslim, Akuntansi Keuangan Syariah teori dan praktek, (CV Pustaka Setia: Bandung, 2015), h. 269.

${ }^{46}$ Wahbah Zuhaily, Al-Fiqhu Al-Islami Wa Adillatuhu, jilid 4, (Damaskus: Dar al-fikr, 2008), h. 514.

$47 \mathrm{Ibid}$, h. 514

${ }^{48}$ Sarib Muslim, Akuntansi Keuangan Syariah..., h. 272-273.

49 Muhammad Sharif Chaudhry, Sistem Ekonomi Islam Prinsip Dasar, (Jakarta: Kencana, 2014), h. 250.
} 


\section{Manfaat Qardhul Hasan}

Qardhul Hasan memiliki beberapa manfaat bagi pihak-pihak yang menggunakannya. Manfaat yang terdapat dalam akad qard, diantaranya adalah:

1. Memungkinkan peminjam yang sedang dalam kesulitan mendesak untuk mendapat talangan jangka pendek, ${ }^{50}$

2. Pedagang kecil memperoleh bantuan dari pemberi pinjaman untuk mengembangkan usahanya, sehingga merupakan misi sosial bagi pihak yayasan dana sosial dalam membantu masyarakat miskin.

3. Adanya misi sosial-kemasyarakatan ini akan mengikat citra baik dan mengikatkan loyalitas masyarakat kepada yayasan dana sosial, karena dapat memberikan manfaat kepada masyarakat golongan miskin. ${ }^{51}$

\section{Skema Qardhul Hasan}

Berikut adalah Skema Pinjaman Qardhul Hasan :52

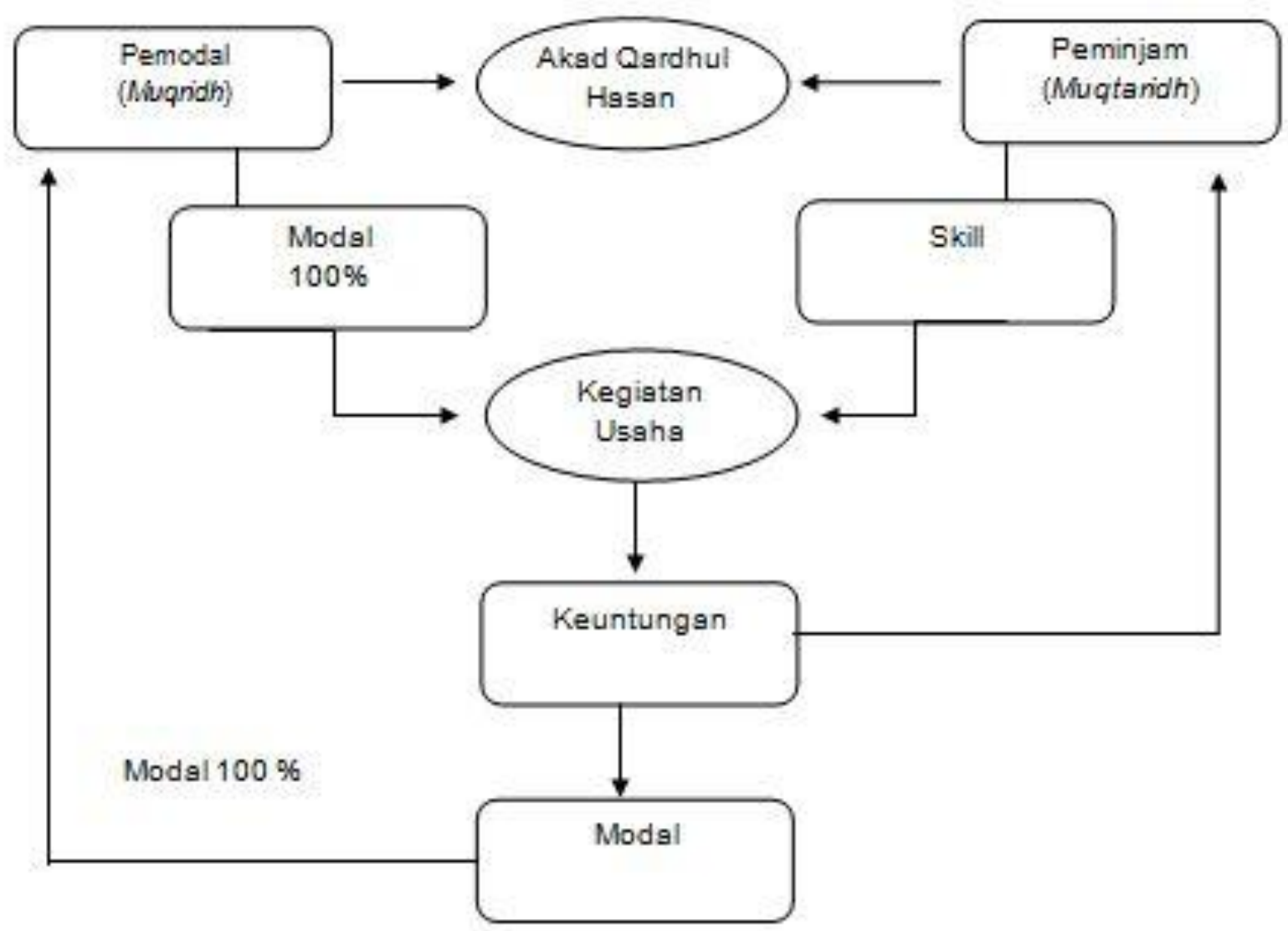

\section{Qardhul Hasan Dalam Persfektif Hukum Islam}

a. Debitur wajib melunasi hutang

Debitur harus mengembalikan hutangnya itu pada waktu atau sebelum jatuh tempo. ${ }^{53}$ Sesuai dengan tuntunan surat al-Ma'idah ayat 1 , bahwa seorang yang beriman diwajibkan oleh Allah untuk memenuhi perjanjian akad-akad yang dibuatnya. Ayat tersebut berbunyi:

\footnotetext{
50 Muhammad Syafi'i Antonio, Bank Syariah dari Teori ke Praktek, h. 134

51 Ismail, Perbankan Syariah, h. 214.

${ }^{52}$ Ascarya, Akad dan Produk Bank Syariah, (Jakarta: Rajawali Pers, 2013), h. 47.

${ }^{53}$ Muhammad Sharif Chaudhry, Sistem Ekonomi Islam..., 249.
} 


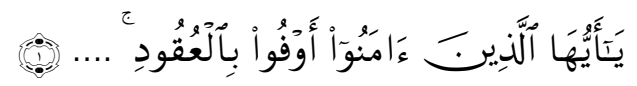

Artinya: "Hai orang-orang yang beriman, penuhilah akad-akad itu...(QS. Al-Maidah : 1) $)^{54}$

Permulaan ayat ini memerintahkan kepada setiap orang yang beriman untuk memenuhi janji-janji yang telah diikrarkan, baik janji prasetia hamba kepada Allah, maupun janji yang dibuat diantara sesame manusia. ${ }^{55}$

Jadi berdasarkan ayat di atas, maka para pihak yang terikat dalam suatu perjanjian (akad) wajib untuk memenuhi klausul-klausul yang telah disepakati dalam perjanjian. Karena itu pihak yang berhutang atau debitur wajib melunasi hutangnya sebagaimana sesuai dengan perjanjian yang telah dibuat dan disepakati bersama. ${ }^{56}$

b. Restrukturasi hutang dan hapus tagih sisa hutang

Konsep Islam mengenai restrukturisasi dan hapus tagih utang debitur dapat kita temui dalam alQur'an antara lain dalam surat al- Baqarah (2) ayat 280 sebagai berikut:

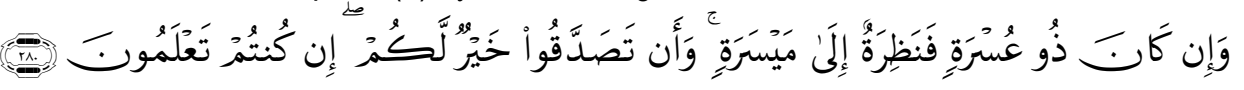

Artinya: "Dan jika (orang berutang itu) dalam kesukaran, maka berilah tangguh sampai dia berkelapangan. Dan menyedekahkan (sebagian atau semua utang) itu, lebih baik bagimu, jika kamu mengetahui." (QS. Al Baqarah : 280) ${ }^{57}$

Ayat di atas adalah sudah sebagai tuntunan kepada orang yang beriman. Hanya orang yang beriman yang mau memberikan kelapangan kepada orang yang berhutang kepadanya. Dan alangkah baiknya jika orang yang berhutang datang meminta maaf dan memohon diberi tempo, kemudian disambut oleh yang memberi hutang dengan perkataan: "hutangmu itu telah aku lepaskan, engkau tidak berhutang lagi". Ayat yang seperti inilah apabila kamu fikirkan, maka amat baik bagi dirimu sendiri. Sehingga dapat mengkokohkan ukhuwah dengan yang diberi hutang. ${ }^{58}$

Berdasarkan ayat al-Qur'an di atas, maka untuk pelaksanaan atau prosedur penanganan dan penyelesaian piutang bermasalah atau pembiayaan bermasalah, dilakukan melalui 3 (tiga) tahap yaitu:

a. Memberi tangguh sampai debitur berkelapangan

Kreditur haruslah cukup dermawan dalam memberi perpanjangan waktu pelunasan jika debitur dalam kesulitan dan tak dapat memenuhi kewajibannya. Tindakan seperti ini merupakan kebajikan yang amat besar dan dijanjikan untuk mendapat pahala sadaqah dari Allah setiap hari hingga utang tersebut dilunasi. ${ }^{59}$

Dengan penangguhan atau penjadwalan pembayaran kewajiban tersebut diharapkan debitur mempunyai kemampuan membayar kembali kewajibannya sehingga dapat melunasi semua hutangnya. Jadi kreditur hanya memberikan perpanjangan jangka waktu pembayaran utang sampai debitur berkelapangan. Dengan demikian penangguhan pembayaran hutang dilakukan dengan cara membuat penjadwalan kembali rescheduling. ${ }^{60}$

b. Menyedekahkan sebagian utang debitur

Apabila setelah diberikan penangguhan kemudian debitur tetap tidak bisa atau tidak mampu melunasi hutangnya tersebut, maka kreditur dapat menyedekahkan piutangnya kepada debitur. Bagi seorang muslim menyedekahkan piutang adalah lebih baik. Dalam al- Qur'an tidak menjelaskan besar kecilnya suatu jumlah piutang yang boleh untuk disadaqahkan. Karena itu,

\footnotetext{
56 Wangsawidjaja Z., Pembiayaan Bank Syariah, (Jakarta: PT Gramedia Pustaka Utama, 2012), h. 400.

57 Departemen Agama RI, Al-Quran Terjemah..., h. 47.

58 Hamka, Tafsir Al Azhar, Juz III, (Jakarta: Pustaka Panjimas, 2003), h. 104.

59 Muhammad Sharif Chaudhry, Sistem Ekonomi Islam..., h. 250

60 Wangsawidjaja Z., Pembiayaan Bank Syariah, h. 402
} 2011), h. 350.

${ }^{54}$ Departemen Agama RI, Al-Quran Terjemah..., 106

${ }^{55}$ Kementerian Agama RI, Al-Qur'an dan Tafsirnya (Edisi yang Disempurnakan), Jilid 2, (Jakarta: Widya Cahaya, 
besar kecilnya jumlah piutang yang akan disadaqahkan tergantung pada kerelaan pihak kreditur atau orang yang meminjamkan hartanya tersebut kepada debitur atau penerima pinjaman. Apabila yang disadaqahkan hanya sebagian dari hutangnya, maka debitur berkewajiban untuk melunasi sisa hutangnya kepada kreditur tersebut. ${ }^{61}$

c. Menyedekahkan seluruh sisa utang debitur

Apabila debitur setelah diberikan kedua tahap tersebut masih dianggap tidak mampu memenuhi kewajibannya, maka terhadap seluruh sisa utang debitur dapat disadaqahkan. ${ }^{62}$

4. Pengalihan Piutang

Pengalihan hutang dapat dilakukan oleh kreditur terhadap debitur yang tidak mampu kepada debitur yang mampu. Hai ini adalah sebagai salah satu bentuk penyelesaian utang-piutang dalam Islam yang dapat dilakukan berdasarkan hadis sebagai berikut:

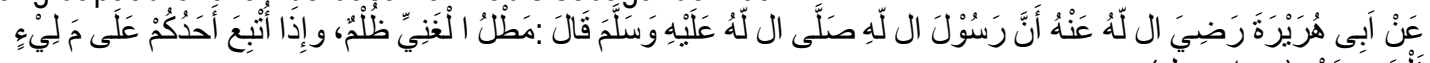

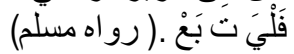

Artinya: "Rasulullah saw. Bersabda: "menunda-nunda pembayaran utang seseorang (padahal dia mampu membayarnya) adalah perbuatan zalim.Dan apabila seseorang diantara kamu mengalihkan piutang kepada orang yang mampu membayarnya, terimalah cara demikian itu". (HR.Muslim). ${ }^{63}$

Hadis di atas berseru kepada orang-orang yang berhutang, bahwasanya apabila menunda hutang bagi orang yang mampu membayar hutang itu adalah sebuah kezaliman. Tetapi apabila tidak dapat membayar hutang karena keadaan yang susah, maka apabila dialihankan hutangnya kepada orang yang lebih mampu diperbolehkan. Sebagai orang yang berhutang maka terimalah keputusan tersebut.

Dengan demikian pembiayaan dalam bentuk piutang qard dapat dilakukan proses restrukturisasi sebagai berikut:

Penjadwalan kembali atau disebut dengan rescheduling. Restrukturisasi yang dilakukan dengan memperpanjang jangka waktu jatuh tempo pembiayaan tanpa mengubah sisa kewajiban peminjam atau penerima hutang yang harus dibayarkan kepada pemberi hutang. ${ }^{64}$

Selain dari penjadwalan kembali proses restrukturisasi dilakukan dengan menetapkan kembali syarat-syarat pembiayaan, antara lain perubahan jadwal pembayaran, jumlah angsuran, jangka waktu, dan atau pemberian potongan sepanjang tidak menambah sisa kewajiban penerima hutang atau debitur yang harus dibayarkan kepada pemberi hutang atau kreditur. Sisa kewajiban yang dimaksud adalah jumlah pokok yang belum dibayarkan oleh penerima hutang atau debitur pada saat dilakukan penataan kembali atau restrukturisasi. ${ }^{65}$

\section{Implementasi Qardh di Baitul Maal wa Tamwil (BMT)}

Qardh sebagai salah satu instrumen keuangan dalam Islam telah mengimplementasikan dibeberapa Lembaga Keuangan Syariah. Diantara Lembaga Keuangan Syariah tersebut adalah Bank Syariah, Baitul Maal wa Tamwil (BMT) dan Unit Simpan Pinjam Syariah. Namun yang akan dibahas oleh penulis hanyalah implementasi qardh di BMT sebagai berikut:

Selain diidentifikasi sebagai lembaga keuangan atau bisnis, BMT juga sering dipahami sebagai lembaga sosial. Pada satu kesempatan BMT dapat menginvestasikan dananya untuk lebih mengembangkan bisnisnya, tetapi pada saat yang lain BMT juga bisa mengembangkan dirinya untuk membantu dalam penyelesaian masalah-masalah sosial, terutama kebutuhan masyarakat yang bersifat konsumtif. Pada hal yang pertama BMT berperan sebagai bayt altamwil dan pada hal yang kedua BMT berperan sebagai bayt al-mal. Pada peran pertama, BMT sebagai bayt al-mal, BMT dapat diidentifikasi sebagai lembaga sosial, yakni lembaga yang berperan untuk ikut menyelesaikan masalah sosial, terutama masalah ekonomi yang dihadapi oleh masyarakat. Hal ini berarti bahwa bagaimana BMT bisa

\footnotetext{
61 Ibid., h. 402

62 Ibid., h. 403

${ }^{63}$ Al-Hafizh Zaki al-Din 'Abd al-'Azhim al-Mundziri, Mukhtashar Shahih Muslim, h. 250.

64 Wangsawidjaja Z., Pembiayaan Bank Syariah, h. 459

65 Ibid., h. 459
} 
menempatkan dirinya sebagai bagian dari lembaga yang dapat mengadvokasi masalah kebutuhan masyarakat yang bersifat konsumtif.

Peran BMT ini antara lain dapat diwujudkan dalam bentuk mengeluarkan produk qardh, yakni pinjaman yang diberikan oleh BMT kepada nasabah dan nasabah hanya mengembalikan pinjaman pokok tanpa ada tambahan apapun. Produk ini dianggap sebagai bentuk kebaikan yang diberikan BMT kepada masyarakat, sehingga istilah yang digunakanpun sering disebut dengan qardhul hasan. Dalam tataran implementasinya, BMT bertindak sebagai muqarridh (pemberi pinjaman), sedangkan nasabah bertindak sebagai muqtaridh.66

Qardh di BMT, bagaimanapun merupakan bagian dari mekanisme kerja yang lebih menonjolkan peran sosial dan non-profit. Namun demikian, hal ini tidak lantas berarti bahwa BMT harus rugi dengan berkurangnya modal finansial. Oleh karena itu, dana yang digunakan untuk qardh ini tidak diambil dari modal BMT, tetapi diambil dari sumber dana lain, seperti hasil pengumpulan zakat, infak dan sedekah. Zakat, infak dan sedekah itu bisa berasal dari zakat, infak dan sedekah BMT itu sendiri maupun dari pihak luar yang menitipkan zakat, infak dan sedekahnya kepada BMT.

Upaya minimalisasi kerugian yang mungkin dialami oleh BMT dalam produk qardh ini dapat dilakukan pula dengan menetapkan bahwa biaya administrasi sepenuhnya ditanggung oleh nasabah. Hal ini selaras dengan apa yang ditetapkan dalam Fatwa DSN MUI Nomor 19/DSN-MUI/IV/2001 bahwa biaya administrasi dalam qardh dibebankan kepada nasabah.

Selain itu, dalam upaya meminimalisasi kerugian BMT yang disebabkan kelalaian nasabah dalam menunaikan kewajibannya, maka BMT berhak meminta jaminan kepada nasabah yang nilainya lebih besar daripada dana yang dipinjam. Apabila nasabah tidak bisa menunaikan kewajibannya, maka BMT bisa menjual jaminan nasabah dan mengambilnya sejumlah dana yang dipinjam nasabah, sedangkan kelebihannya diserahkan kepada nasabah. ${ }^{67}$

\section{Simpulan}

Berdasarkan hasil penelusuran dan pembahasan tentang analisis Qardhul Hasan dalam Persfektif Hukum Islam pada Baitul Maal wa Tamwil (BMT) dan implementasinya, dapat ditarik kesimpulan bahwa: Al Qardhul Hasan adalah akad yang dikhususkan pada pinjaman dari harta yang terukur dan dapat ditagih kembali serta merupakan akad saling bantu-membantu dan bukan merupakan transaksi bisnis secara komersial. Sumber dana qardh diambil dari Bagian modal LKS yaitu Baitul Maal wa Tamwil (BMT), Keuntungan yang disisihkan, dan Lembaga lain atau individu yang mempercayakan penyaluran infaqnya kepada BMT. Salah satu fungsi Lembaga Keuangan Syariah (LKS) termasuk Baitul Maal wa Tamwil (BMT) adalah disamping sebagai lembaga komersial juga ikut serta dalam kegiatan sosial yang dapat meningkatkan perekonomian secara maksimal, yang diaplikasikan dengan menyalurkan dana dalam bentuk qardh. Pembiayaan Qardhul Hasan di BMT bersumber pada dana pembiayaan qardhul hasan berasal dari dana cadangan koperasi yang didapat dari sisa bagi hasil pembiayaan lainnya. Dampak yang dirasakan oleh anggota setelah menerima pembiayaan qardhul hasan adalah dapat membantu karena dapat membayar biaya pendidikan dan biaya lainnya dengan tanpa ada tambahan sedikitpun dari segi besaran dan waktunya pun tidak ditentukan jadi tidak memberatkan.

\section{Referensi}

A. Azhar Basyir, Hukum Perkawinan Islam. juga Fuad Kauma \& Nipan, Membimbing Istri

Abdurrachaman Qadir, Zakat (Dalam Dimensi Mahdah Dan Sosial), Ed.1.Cet.2 (Jakarta: Raja Grafindo Persada, 2001)

Abdurrahman al-Jaziri, Kitab Fiqih Empat Madzhab, (CV. Asy Syifa', Semarang, 1994)

66 Dr. Yadi Janwari, Fikih Lembaga Keuangan Syariah (Bandung: PT. Remaja

Rosdakarya, 2015), h. 151.

67 Ibid., h. 152 
Adiwarman karim, Bank Islam Analisis Fiqih dan Keuangan, (Jakarta: PT RajaGrafindo Persada, 2004)

Ahmad Wardi Muslich, Fiqih Muamalat (Jakarta: Amzah, 2010)

Al-Hafizh Zaki al-Din 'Abd al-'Azhim al-Mundziri, Mukhtashar Shahih Muslim,

Amir Machmud dan Rukmana, Bank Syariah Teori, Kebijakan...,

Andri Soemitra, M.A., Bank dan Lembaga Keuangan Syariah, Edisi Pertama (Jakarta : Kencana Prenadamedia Group, 2009)

Ascarya, Akad \& Produk Bank Syariah. (Depok: Raja Grafindo Persada Jakarta, 2015), Cetakan ke-5

Atang Abd. Hakim, Fiqih Perbankan Syariah, (Bandung: PT Refika Aditama, 2011)

Dedi Riswandi, Pembiayaan Qardhul Hasan Di Bank Syariah Mandiri Kota Mataram, Jurnal Hukum Islam, Vol. 14, No. 2, (2015)

Dr. Yadi Janwari, Fikih Lembaga Keuangan Syariah (Bandung: PT. Remaja Rosdakarya, 2015)

Drs. Ismail, MBA., Ak., Perbankan Syariah, (Jakarta: Kencana, 2011)

DSN MUI, Qard, Fatwa DSN MUI. No. 19/DSN-MUI/IV/2001 Tentang Qard

Fatwa MUI, Dalam Perspektif Hukum dan Perundang-undangan, (Puslitbang Keagamaan Badan Litbang dan Diklat, Jakarta, 2012)

Hamka, Tafsir Al Azhar, Juz III, (Jakarta: Pustaka Panjimas, 2003)

Hendri Hermawan A. N, Sumber dan Pengunaan Dana Qardh dan Qardhul Hasan, (La Riba Jurnal Ekonomi Islam volume 11. No, 2 Desember 2008)

Imam al-Buhari dan Abu Hasan al-Sindi, Sahih al-Buhari bihasiyat al-Imam al-Sindi, juz II, (Lebanon: Dar al-Kitab al-IImiyah, 2008)

Ismail, Perbankan Syariah, (Jakarta: Kencana, 2011)

Karnaen Perwataatmadja dan Muhammad Syafi'i Antonio, Apa dan Bagaimana Bank Islam (Yogyakarta: Dana Bhakti Wakaf, 1992)

Kementerian Agama RI, Al-Qur'an dan Tafsirnya (Edisi yang Disempurnakan), Jilid 2, (Jakarta: Widya Cahaya, 2011)

Muhamad Bisri Mustofa, Hukum Nafkah Terhadap Keluarga pada Gerakan Dakwah Jama'ah Tabligh, Jurnal Nizham, Vol. 7, No. 1 (2019)

Muhammad Akhyar Adnan, Evaluasi Performing Loan (NPL) Pinjaman Qardhul Hasan (Studi Kasus di BNI Syariah Cabang Yogyakarta), Jurnal Perbankan, Vol. 10, No. 2

Muhammad bin Ismail Al-Amir Ash-Shan'ani, Subulus Salam Syarah Bulughul Maram, Penerj. Ali Nur Medan, Jilid 2, (Jakarta: Darus Sunnah Press, 2008)

Muhammad Muslehuddin, Sistem Perbankan dalam Islam, (Rineka Cipta, Jakarta, 2004)

Muhammad Sharif Chaudhry, Sistem Ekonomi Islam Prinsip Dasar, (Jakarta: Kencana, 2014)

Muhammad Syafi'i Antonio, Bank Syariah dari Teori ke Praktik (Jakarta: Gema Insani, 2001)

Muhammad, Bank Syariah: Problem dan Prospek Perkembangan di Indonesia, (Yogyakarta: Graha IImu, 2005)

Muhammad, Sistem dan Prosedur Operasional Bank Syariah, (Yogyakarta: UII Press, 2000)

Muhammad, Tehnik perhitungan Bagi Hasil dan Profit Margin pada Bank Syariah, (UII Press, Yogyakarta, 2004)

Mulyaningrum, Peluang dan Tantangan dalam Pengembangan Lembaga Keunagan Mikro Syariah, (Tesis tidak diterbitkan, Universitas Kebangsaan Malaysia (UKM), 2009)

Rachmat Syafe'i, Fiqh Muamalah, (Pustaka Setia: Bandung, 2001)

Ridwan, M., Managemen Baitul Maal Wa Tamwil, (Yogyakarta: UII Press Yogyakarta, 2004), Cet. Pertama

Rijal Yaya, Aji Erlangga Martawireja, Ahim Abdurahim, Akuntansi Perbankan Syariah Teori dan Praktik Kontemporer, (Jakarta: Salemba Empat, 2014)

Sarib Muslim, Akuntansi Keuangan Syariah teori dan praktek, (CV Pustaka Setia: Bandung, 2015)

Sunarto Zulkifli, Panduan Praktis Transaksi Perbankan Syariah, (Jakarta: Zikrul Hakim, 2007) 
Sutan Remy Sjahdeini, Perbankan Syariah Produk - Produk dan Aspek-Aspek Hukumnya, (Jakarta: Kencana, 2014)

Wahbah Al-Zulayle, Financial Transaction in Islamic Jurisprudence (Translation of Al- Fiqh al-Islemiy wa 'Adillatuh), Vol.1

Wahbah Zuhaily, Al-Fighu Al-Islami Wa Adillatuhu, jilid 4, (Damaskus: Dar al-fikr, 2008)

Wangsawidjaja Z., Pembiayaan Bank Syariah, (Jakarta: PT Gramedia Pustaka Utama, 2012)

Wini Arintasari, Analisis Sistem Pengendalian Intern Terhadap Keputusan Persetujuan Pembiayaan pada Koperasi Jasa Keuangan Syariah di Baitul Maal wa Tamwil Anda Salatiga (Salatiga: Skripsi tidak diterbitkan, 2013) 